\title{
Printed Graphics in the Educational Process of Training the Artist Pedagogue
}

\author{
Oros Ivan Vasilyevich \\ Senior Lecturer of the Department of Theory and Methodology of Decorative \\ Arts, graphic arts and graphic faculty of the State institution "South Ukrainian \\ National Pedagogical University named after K. D. Ushinsky"
}

\begin{abstract}
In the article the discipline "Printed Graphics" is considered and its creative possibilities and its role in educational process of training of future artists-teachers are revealed. It is noted that one of the priority tasks defined by the National Doctrine of Pedagogical Education Development in Ukraine is the creation of preconditions for the education of a teacher - a person capable of creative thinking, to take non-standard creative decisions on their own, to flexibly respond to changes in conditions of restructuring the aesthetic sphere of society. It turns out that modern practice demonstrates the lack of a comprehensive study of printed graphics as a specific discipline in the system of artistic education in the process of forming an artist-teacher. The stated purpose of the study is the need to disclose the creative possibilities of print graphics and its role in the educational process and to identify the territorial and methodological principles of training the artist - the teacher through means of printed graphics.

Conclusions provide some generalizations. Formation and development of future artists-teachers is connected with discipline "Printed graphics", proceeding from its creatively-developing features, comprehension, assimilation of content of classes, creative use of available knowledge, obtaining practical skills. The success of the study of printed graphics is due to the creative use of the interconnection between different types of art, the optimal correlation between theoretical and practical classes, the degree of mastering the language of graphic arts, the ability to use acquired knowledge and technical skills in creative work. Purposeful realization of pedagogical possibilities in the study of printed graphics on practical classes in the workshop of printed graphics acts as a pedagogical necessity. The developed and tested method of certain pedagogical units of teaching printed graphics activates the development of creative and pedagogical abilities of future artists teachers, which is related to the discipline "Printed graphics".
\end{abstract}

Key words: printed graphics, types of printed graphics, teaching methods of printed graphics, pedagogical approach.

Introduction. One of the priority tasks defined by the National Doctrine of Pedagogical Education Development in Ukraine is the creation of preconditions for the education of a teacher - a person capable of creative thinking, to take non-standard creative decisions on his own, to flexibly respond to changes in the context of restructuring the aesthetic sphere of society. In connection with this, the modernization of the national education system and the development of the latest concepts of the education of the artist-teacher are taking place. 
In this context, an appeal to printed graphics in the educational process as a type of artistic art is important, which has a significant influence on the education of a creative personality - students of pedagogical universities. Thanks to, for example, easel art, it gives the opportunity to receive learning outcomes in the form of genuine copyrights, not reproductions.

The degree of development of the problem. The problem of theory and methodology of graphics was engaged in many artists - teachers of the past and the present, such as Leonardo da Vinci, A. Durer, E. Delacroix, J.-B. Engr, P. Chistyakov, I. Repin, V. Serov, I. Grabar, B. Johanson, D. Kardovsky, N. Krymov, V. Yakovlev and others. In the works by N. Volkova , E. Kibrica, В. Дехтерєва B. Favorsky, B. Johanson, I. Verby [2], A. Gritsaya, A. Goncharova [3], V. Efanova, M. Manizher V. Timoshevsky [6], V. Khristenko [7] and others are developed the conceptual foundations of printed graphics.

The determination of the state of aesthetic education and the artistic education of students by means of artistic and printed graphics, as well as the process of educational and creative activity on the subject during classes in the workshop is reflected in N. Anisimova, A. Aleikhina, R. Barciza [1], G. Vinogradova, V. Winch, V. Koreshkova, V. Kuzina, B. Likhacheva, N. Bogolyubova, N. Rostovtseva, N. Tkachenko, A. Khvorostova, E. Shorokhova, T. Spikalova and others.

Insufficiently highlighted aspects of the problem. Modern practice demonstrates the lack of a comprehensive study of printed graphics as a specific discipline in the artistic education system in the process of forming an artist-teacher. This implies that this is a multifaceted problem, which is mainly considered through the prism of traditional notions in high school, and is not sufficiently researched.

The purpose of the study is to reveal the creative possibilities of printed graphics and its role in the educational process and to identify the tereko - methodological principles of preparing an artist - a teacher by means of printed graphics.

The main content (research methodology). Today, the professional competence of a modern artist-teacher is a complex multicomponent concept, which in psychological and pedagogical literature is characterized from the point of view of different approaches: sociocultural, activity, communicative, professional, context-informational and psychological. 
But each of these approaches, despite the fact that all these approaches are interconnected and mutually complementary, do not exhaust the problems of professional training to the full, and therefore needs to be complemented by this problem.

The main content (Discussion). One of the ways is to apply to printed graphics as a particular type of art in the process of teaching students in artistic education. Printed graphics are spatial types of art and each type of art has its own specifics, sets its own tasks and creates for their solution their means and techniques, a certain peculiarity of artistic possibilities that forms its figurative and expressive language. Graphic language allows you to leave and receive information, use it to everyone without exception. Of course, all the information is so large that it can be noted as a sign of infinity, and it is divided into the right one at the moment and unnecessary. In the graphic information the image is transformed (interpretation) - displaying graphically using lines, dots, spots (images) and using characters, fonts (text) [2].

Print is one of the branches of graphics. Under the graph, the graphic work is depicted, printed with any printing form, processed in one way or another by printing: in a machine or manual, and an independent value, which has in this case. It is usually performed in one of three main types: engraving, lithography, or etching. Linogravure, xylography, etching, lithography - all these forms of modern graphics are united by the general notion of "emblems". The mass of copies, a small format, makes the printers modern, so easily included in all areas of life. Interiors of apartments, hotels, cafes, libraries, exhibitions are unbelievable now without any prints.

In print graphics, the distribution of print types (high print, deep, flat and penetrating) plays an important role. Understanding of these technological processes of printing, influencing thinking in the material, and knowledge of all types of printed graphics (etching, wood engraving, lithography, silkscreen).

In general, in the process of preparing students, printed graphics are an integral part of the educational process at the art and graphic faculty. Classroom practice involves the development of students of a number of specific qualities, among which it is possible to distinguish a particular professional culture and the ability to form an artistic image in more conventional forms than in painting. 
One of the aspects determining the relevance of modern artistic and pedagogical education in higher education is the lack of theoretical and methodological developments in technology and technology of print graphics, which negatively affects the processes of artistic and pedagogical preparation of students. The educational process should be based on the scientific and methodological basis with the use of visibility.

The technique of printed graphics provides unique opportunities for artistic experiment and expression of the artist's outlook directly in the process of work, and many of the artists made sure of this in their own experience.

Systematic studies of various types and subspecies of printed graphics, as noted, in particular, by R. Bartsitz, the study of techniques and technology of art of the editors actively influence the process of forming the aesthetic taste of students. In the process of educational and creative activity in the studio, students of the arts and graphic faculties of the pedagogical universities receive theoretical knowledge and practical skills in work on the creation of graphic composition, get acquainted with the traditions and techniques of artistic and printed graphics (linocut, xylograph, engraving, dry needle, etching - etching bar, monotypia, lithography, etc.). The practical activity of students in the workshop of graphics in the classroom on the subject of "graphic composition" is fundamental, since it actively promotes aesthetic education and artistic education of students, develops creative abilities in the field of graphic composition, activates creative thinking [1].

Based on the pedagogical experience, special studies, it is possible to formulate general requirements for the optimal combination of teaching methods of print graphics. General requirements for the educational process of preparing the artist - training in classroom lessons is based on the fact that the use of the whole set of teaching methods in their numerous combinations and combinations provides high efficiency student training. The leading role always belongs to the teacher, and the success of the educational process depends on how substantiated, appropriate and skillfully he applies specific teaching methods.

Methods of teaching are classified into general (can be used in the process of teaching any subjects) and special (they are used for the teaching of certain subjects, but can not be used in the teaching of other subjects). The visual teaching methods include: illustration, demonstration, independent observation. The method of illustration is to equip illustrations of 
visibility, posters, drawings, paintings and other. Method of demonstration - display of visual means. The display of various visual objects - real objects and their images in the works of artists.

By the criterion of reflection, the means of visibility can be: natural objects - plants, animals, tools and products of labor, minerals, chemicals, etc. Specificity, completeness, versatility of natural objects can not replace artificial images; figurative (mediating) means graphic works, paintings, reproductions of art paintings, mock-ups, dummies, and others. Their value is that they in a bright figurative form reflect complex objects and phenomena. When using them, attention is drawn to the inner essence of the images in order to teach them to read the picture, to show the main thing in it - the idea, image, basic content. It also focuses on the most significant features and features of objects presented in the form of models, models, sculptures (general structure of the subject, its main parts, interdependence between them); schematics-paintings, work in the tinctures of printed graphics.

Practical teaching methods are needed to deepen knowledge, to develop skills and abilities. They include: exercises, practical, graphic and creative - research work. Creative exercises act as a purposeful, repeated repetition by students of certain actions and operations for the formation of skills and abilities. Graphic works are performed on assignments and under the guidance of a teacher. Applied during the study of theoretical material at all stages of learning.

Conclusions. On the basis of the conducted research it is possible to make certain generalizations:

- Formation and development of future artists-teachers is connected with the discipline "Printed graphics", proceeding from its creatively-developing features, comprehension, mastering the content of classes, the creative use of available knowledge, and the acquisition of practical skills.

- The success of the study of printed graphics is due to the creative use of the interconnection between different types of art, the optimal correlation between theoretical and practical classes, the degree of mastering the language of graphic arts, the ability to use acquired knowledge and technical skills in creative work. 
- Purposeful implementation of pedagogical opportunities in teaching print graphics on practical classes in the workshop of printed graphics acts as a pedagogical necessity.

- The developed and tested method of certain pedagogical units of training of print graphics activates the development of creativity and pedagogical abilities of future artists teachers, which is related to the discipline "Printed graphics".

Prospects for further research. In our opinion necessary new approach to printed graphics in the educational process as a type of artistic art is important, which has a significant influence on forming of students' creative personality in the conditions of university.

\section{References}

1. Bartsits R. Ch. Theory and practice of teaching print design to students of artgraphic faculties of pedagogical universities: Dis. ... Dr. Ped. Sciences. Specialty: 13.00. 02, Moscow. 2001. 543 p.

2. Verba I. Art graphs, K.: Radyanska School. 1968. 100 p.

3. Goncharov A. About the art of graphics, Moscow: Young Guard. 1960. 344 p.

4. Kolycheva, T.V. Scientific and Artistic Cognition: Their Specificity and Interaction: avtoref. to Dis ... Cand. Philos. Sciences. Specialty: 09.00.01. Kharkiv. 2004. 17 p.

5. A new view on the art of Ukrainian graphic arts of the twentieth century // Artistic horizons. Kyiv: AUM, 2002. Issue 3. P. 40-45.

6. Timoshevsky V. Estamp. 1995. Kharkiv. 93 p.

7. Khristenko B. Techniques of the author's printing. Kharkiv: Color. 2007. 721 p. 